\title{
A small-scale fishery near a rocky littoral marine reserve in the northwestern Mediterranean (Medes Islands) after two decades of fishing prohibition
}

\author{
PALOMA MARTÍN ${ }^{1}$, FRANCESC MAYNOU ${ }^{1}$, VANESSA STELZENMÜLLER ${ }^{2}$ \\ and MIQUEL SACANELL ${ }^{1}$ \\ ${ }^{1}$ Institut de Ciències del Mar (ICM-CSIC), Passeig Marítim de la Barceloneta, 37-49, 08003 Barcelona, Spain. \\ E-mail: paloma@icm.csic.es \\ ${ }^{2}$ Johann Heinrich von Thünen Institute (vTI), Federal Research Institute for Rural Areas, Forestry and Fisheries, \\ Institute of Sea Fisheries, Palmaille 9, 22767 Hamburg, Germany.
}

\begin{abstract}
SUMMARY: Fishing in the Medes Islands Marine Reserve (511 ha, including a no-take zone and a buffer area) was prohibited in 1983. This study is the result of a 2.5 -year monitoring program (sampling on board fishing boats from June 2003 to December 2005) aimed at characterizing the small-scale fishing carried out near the reserve. A total of 109 species were identified. The various métiers in use with the fishing gears trammel net, longline and gillnet were identified on the basis of the landing profiles. The main fishing target species included striped red mullet (Mullus surmuletus), common sole (Solea solea), gilthead seabream (Sparus aurata), common cuttlefish (Sepia officinalis), common pandora (Pagellus erythrinus), seabass (Dicentrarchus labrax), spiny lobster (Palinurus elephas) and hake (Merluccius merluccius). Most of the catches consisted of mature individuals and discards were very low or nil. The exception was Palinurus elephas, with catches made up mostly of juveniles. The estimated stock parameters for Mullus surmuletus, Pagellus erythrinus, Sparus aurata and Scorpaena porcus $\left(\mathrm{L}_{\mathrm{c}}\right.$ mean catch length; $\mathrm{L}_{\mathrm{opt}}$ length at maximum yield per recruit; $\mathrm{Y} / \mathrm{R}_{\mathrm{c}} ; \mathrm{Y} / \mathrm{R}_{\max } ; \mathrm{Y} / \mathrm{R}$ at $\mathrm{F}_{(0.1)}$, $\left.\mathrm{Y} / \mathrm{R}_{(0.1)}\right)$ and the distributions of the exploited sizes, with presence of very large individuals, suggest a situation of low fishing pressure.
\end{abstract}

Keywords: small-scale fishery, métier, NW Mediterranean, marine reserve, Medes Islands.

RESUMEN: LA PESCA ARTESANAL CERCA de UNA RESERVA MARINA LITORAL ROCOSA EN El MEDITERRÁNeo NOROCCIDENTAL (Islas Medes) Después de dos déCAdAs de Limitación De la aCtividad PESQuera. - En 1983 se prohibió la pesca en la reserva marina de las Islas Medes (511 ha, con una zona estrictamente protegida y una zona parcialmente protegida). Este estudio es el resultado de un programa de seguimiento (muestreo a bordo de barcas de pesca desde junio de 2003 a diciembre de 2005) para la caracterización de la pesca artesanal realizada cerca de la reserva. Fueron identificadas un total de 109 especies. En base a los perfiles de captura y para trasmallo, palangre y beta, se identificaron los distintos métiers en uso. Las principales especies objetivo de la pesca incluyeron el salmonete de roca (Mullus surmuletus), lenguado (Solea solea), dorada (Sparus aurata), sepia (Sepia officinalis), breca (Pagellus erythrinus), lubina (Dicentrarchus labrax), langosta (Palinurus elephas), merluza (Merluccius merluccius). La mayor parte de la captura estuvo constituida por ejemplares maduros y los descartes fueron muy bajos o inexistentes. La excepción fue Palinurus elephas, con capturas constituidas mayoritariamente por juveniles. Los parámetros estimados para los stocks de Mullus surmuletus, Pagellus erythrinus, Sparus aurata y Scorpaena porcus $\left(\mathrm{L}_{\mathrm{c}}\right.$ talla media de captura; $\mathrm{L}_{\mathrm{opt}}$ longitud en el máximo rendimiento por recluta; $\mathrm{Y} / \mathrm{R}_{\mathrm{c}} ; \mathrm{Y} / \mathrm{R}_{\max } ; \mathrm{Y} / \mathrm{R}$ a $\mathrm{F}_{(0.1)}$, $\mathrm{Y} / \mathrm{R}_{(0.1)}$ y las distribuciones de tallas explotadas, con presencia de ejemplares de gran tamaño, sugieren una situación de baja presión pesquera.

Palabras clave: pesca artesanal, métier, Mediterráneo NO, reserva marina, Islas Medes. 


\section{INTRODUCTION}

Marine reserves are primarily a tool for conservation of marine seascapes and their biological diversity. The establishment of marine reserves has been shown to result in long-lasting and sometimes rapid increases in the abundance, diversity and productivity of marine organisms. The observed benefits do not apply to all species at all times, however. In particular, the response of target commercial species, i.e. the direct effect of marine reserve protection on fishery resources, is relatively rapid and expected to be related to fish commercial value and size (e.g. Claudet et al. 2006, 2008, Babcok et al. 2010).

Small-scale fisheries in Europe are a use of the coastal zone that is increasingly threatened by competition from other extractive uses (large-scale fleets and recreational fisheries) and other non-extractive uses (e.g. tourism). In 2009 the European fishing fleet consisted of 84900 vessels. Of these, more than $80 \%$ were vessels of less than $12 \mathrm{~m}$ length, i.e. small-scale fishing vessels (European Commission 2010). These fisheries are highly dependent on local conditions of fish productivity, species availability, fishing gear and fishing traditions. Because of their relatively small economic importance, they are not well covered by European regulatory and management frameworks, but their importance in social terms is locally significant (Colloca et al. 2004, Guyader 2007, Tzanatos et al. 2008, García- Rodríguez et al. 2006, Gómez et al. 2006).

Many Mediterranean marine reserves are located near rocky coasts or islands, and a zonation of usages is almost always practiced, ranging from no-take zones to controlled extractive activities. Professional fishing is totally prohibited in some of them, while in others only a portion of the protected area is closed and some modalities of small-scale fishing are allowed (for a review of the characteristics of the marines reserves established in the northwestern Mediterranean, see Francour et al. 2001, Vandeperre et al. 2008).

The Medes Islands Marine Reserve, a small archipelago in the NW Mediterranean, was established in 1983. The first proposal aimed at creating a submarine park in the Medes Islands was made in 1971 (Ballester 1971). The reserve lies 1 mile offshore of the fishing port of L'Estartit. Before 1983, the use of trammel nets and longline and spear fishing was common in the reserve and trawlers used to operate very close to the rocky grounds. Nevertheless, the driving force for the creation and design of the Medes Islands Marine Reserve was not fisheries enhancement, but nature conservation. The first protection measure implemented in 1983 was the prohibition of fishing and extraction of living marine resources within $75 \mathrm{~m}$ of the Medes Islands. In 1991 this area was extended to a radius of $200 \mathrm{~m}$, the different uses and activities carried out in the marine reserve were for the first time regulated, and the need to set a limit to frequentation by divers was acknowledged. Diving is limited to 60000 dives per year, with a maximum of 450 dives per day. The Medes Islands Marine Reserve is part of the Natura 2000 network.

At the Medes Islands there has been a dramatic increase in non-extractive uses and tourism-related activities. The amount of fishing is now symbolic. Because artisanal fishing is a traditional activity, the knowledge and expertise were learnt by family tradition. By the late 1980s the fishing fleet of L'Estartit consisted of 30 small vessels using trammel net and gillnet and 7 using longline. These boats operated around the Medes Islands and in the rocky coastal zones north of the fishing port (Lleonart 1990). Fishing is seasonal because weather conditions limit the activity in winter. In summer, when the economic activity is focused on tourism, fishing activity is lower than in spring and autumn.

The biological monitoring of the Medes Islands Marine Reserve started in 1990, with the aim of assessing the changes in its natural heritage and providing criteria for the management of the reserve. The monitoring is part of the scientific research conducted at the Medes Islands, which makes this small archipelago one of the most studied areas in the Mediterranean. Monitoring targets include Posidonia oceanica meadows, the gorgonian Paramuricea clavata, red coral Corallium rubrum, the sea urchin Paracentropus lividus, the European spiny lobster Palinurus elephas, the dusky grouper Epinephelus marginatus and fishes at the community level. Earlier studies have assessed the reserve performance and effects on adult fish (García-Rubies and Zabala 1990, Macpherson et al. 2000, Hereu et al. 2006), ichthyoplankton (Sabatés et al. 2003, LópezSanz et al. 2009, 2011), crustaceans (Díaz et al. 2005), red coral (Tsounis et al. 2006), and sea urchins (Hereu et al. 2005). Despite this considerable research effort the fishing activity was not taken into account in the long-term study of the performance of the marine reserve.

Recent studies addressed this knowledge gap on the patterns and drivers of the fishing activity around the Medes Isles and on the ecological and fisheries effects of the marine reserve. For instance, the spatial assessment of fishing effort and patterns of species and functional diversity, as well as the bioeconomic effects on species conservation, commercial fishing, and tourist activities were analysed by Stelzenmüller et al. (2007, 2008, 2009) and Merino et al. (2009). However, these initiatives focused on specific research questions regarding the effect of protection than on a comprehensive characterization of the artisanal fishing activities around the Medes Isles. Such a characterization is crucial for the provision of baseline information for further monitoring changes in the fishing activity and catches. Further data on changes in catches and their variances are important for the parameterization of population models or bioeconomic models (Holland 2000, Holland et al. 2005, Merino et al. 2009)

Therefore, the objective of this study was to characterize the fishing activity around the Medes Islands 


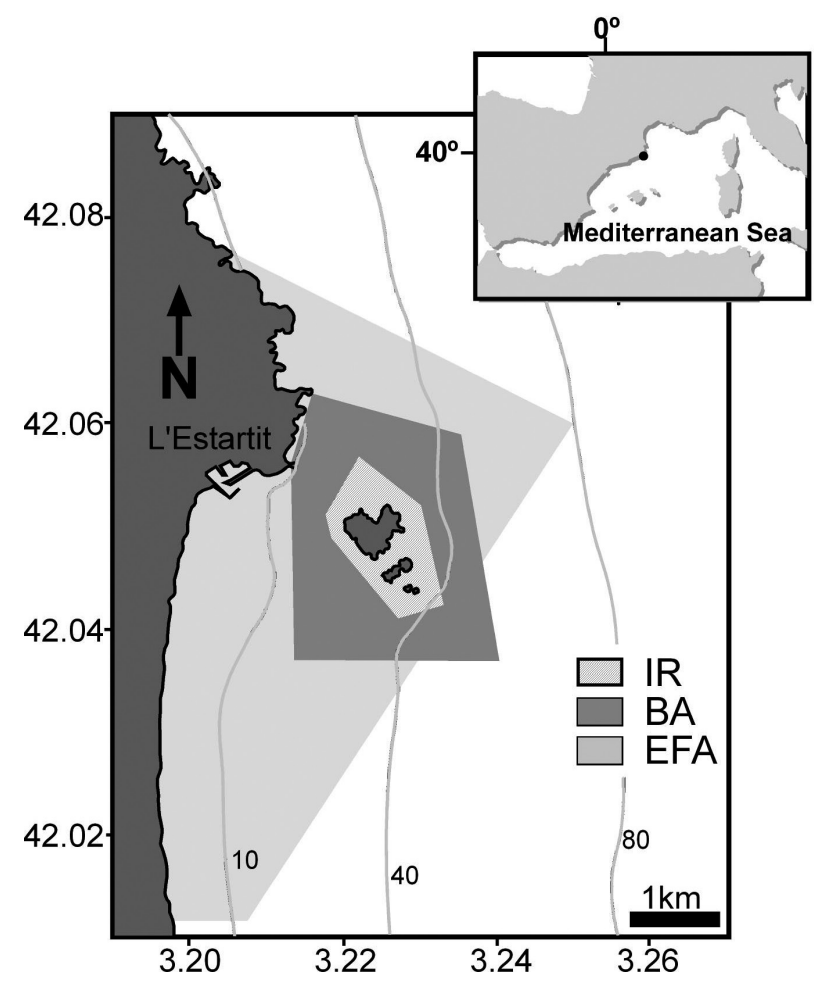

FIG. 1. - Study area with the limits of the Medes Islands Marine Reserve (IR, Integral Reserve; BA, buffer area; EFA, Estimated Fishing Area), showing the area where L'Estartit fleet predominantly operates (from Merino et al. 2009, modified).

Marine Reserve and to assess the status of the exploited fish stocks. To this end, overall data on the catch by fishing gear are presented; the various métiers in use are identified and characterized (specific composition of the catch by métier); and the size distributions of target species expected to respond to protection (striped red mullet Mullus surmuletus, common pandora Pagellus erythrinus, gilthead seabream Sparus aurata, black scorpionfish Scorpaena porcus, spiny lobster Palinurus elephas and common cuttlefish Sepia officinalis) are also given and analysed to illustrate the status of exploitation.

\section{MATERIALS AND METHODS}

\section{Study area}

The small archipelago of the Medes Islands Marine Reserve, located 1 mile offshore of the fishing port of L'Estartit, consists of seven small uninhabited islands and islets and a few rocky reefs (Fig. 1). The marine reserve has a total area of 511 ha (emerged zone not included) and encompasses a buffer area (418 ha) and an integral reserve (93 ha). In the buffer area and the integral reserve, diving, anchoring and navigation are allowed or regulated. Artisanal and recreational fishing are allowed only in the buffer area. The area where the activity of the artisanal fishing is concentrated (the buffer and non-protected zone) has been estimated to be 3800 ha (Merino et al. 2009, based on a spatial analysis by Stelzenmüller et al. 2007). Only the fishing boats based in L'Estartit are allowed to fish near the marine reserve. At the time when sampling was conducted (2003-2005) the number of registered boats was 24 (mean length of $6.5 \pm 1.3 \mathrm{~m}$ and mean horsepower of $30 \pm 16 \mathrm{hp}$; 1 fisherman per boat), but only 7 fishermen fished all year round. Taking into account the weather conditions in the area, which restricts fishing in winter, and the regulations (fishing is allowed 5 days a week), fishing can be practiced around 120 days a year.

As in other Mediterranean artisanal fisheries, the target species change during the year. The number of fishermen and boats is small, so the characteristics of the boats and fishing gears for the different métiers remains fairly similar. The boats used for gillnet and longline were of larger size and horsepower (mean length of $7.0 \pm 1.0 \mathrm{~m}$ and $7.7 \pm 0.6 \mathrm{~m}$ and mean horsepower of $44 \pm 5 \mathrm{hp}$ and $46 \pm 2 \mathrm{hp}$, respectively) than those used for trammel net (mean length of $5.9 \pm 1.1 \mathrm{~m}$ and mean horsepower of $24 \pm 16 \mathrm{hp}$ ). The gear length of the sampled sets was $900 \pm 500 \mathrm{~m}$ for trammel net, with the mode at $1000 \mathrm{~m} ; 2600 \pm 1000 \mathrm{~m}$ for longline, with the mode at $2000 \mathrm{~m}$; and $1200 \pm 550 \mathrm{~m}$ for gillnet, with the mode at $1100 \mathrm{~m}$. It is worth noting that the fishing regulation for the marine reserve limits the length of the gear to 20 units of $60 \mathrm{~m}$ per boat for trammel net and 5 units of $1500 \mathrm{~m}$ per boat for longline (Generalitat de Catalunya, 2008).

\section{On-board sampling}

Sampling was carried out on board seven artisanal fishing boats (2003-2005; 157 days at sea; 223 sets sampled, 207 sets valid and retained for analysis; $2600 \mathrm{~kg}$ total weight sampled; 109 species identified). Sampling was conducted from March to December. The fishing boats used during sampling include those that go fishing regularly all year. The fishing gears that were used during the sampling were trammel net, gillnet, longline, traps, boat seining (locally called "sonsera") and handlining (Table 1, including non-commercial species). Data collected on board include date; information on the fishing ground (position, depth, type of bottom); weather and sea condition; duration (the period the set was soaked, initial and final time); specific composition of the catch (for the commercialized fraction and discards, if any); number and weight, by species (if weighing was not possible on board, weight was estimated later in the laboratory using the corresponding length-weight relationship); and characteristics of the fishing gear. All individuals were measured (fishes and spiny lobster, total length; cuttlefish, mantle length) to the nearest $\mathrm{cm}$.

The most frequently used fishing gears are trammel net, gillnet, longline and traps. Traps were used by one retired fisherman and the target species was the common octopus, Octopus vulgaris. Other gears, such as "sonsera" (boat seine targeting sand eel Gymnammo- 
TABLE 1. - Species recorded during the sampling on board (2003-2005), with indication of the fishing gear that caught the species (G, gillnet; $\mathrm{T}$, trammel net; L, longline; TP, trap; $\mathrm{H}$, handline; $\mathrm{S}$, boat seine).

CNIDARIA

Corallium rubrum

Leptogorgia sarmentosa

Rhizostoma pulmo

ECHINODERMATA

Coscinasterias tenuispina

Echinaster sepositus

Echinus melo

Marthasterias glacialis

Paracentrotus lividus

Stichopus regalis

MOLLUSCA Gastropoda

Aplysia fasciata

Bolinus brandaris

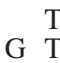

MOLLUSCA Cephalopoda

Illex coindetii

Loligo vulgaris

Octopus vulgaris

Sepia officinalis

\section{CRUSTACEA}

Calappa granulata

Dardanus arrosor

Galathea strigosa

Homarus gammarus

Maja squinado

Palinurus elephas

Paromola cuvieri

Parthenope macrochelos

Penaeus kerathurus

Squilla mantis

PISCES Chondrichthyes

Dasyatis pastinaca

Myliobatis aquila

Raja clavata

Raja undulata

Scyliorhinus canicula

Torpedo marmorata

Torpedo torpedo

\section{PISCES Ostheichthyes}

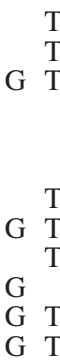

Argyrosomus regius

Arnoglossus spp.

Auxis rochei

Belone belone

Boops boops

Bothus podas

T Chelidonichthys cuculus

Chelidonichthys lucerna

Chelon labrosus

Chromis chromis

Citharus linguatula

Conger conger

Dactylopterus volitans

Dentex dentex

Dicentrarchus labrax

Tiplodus annularis

Diplodus puntazzo

Diplodus sargus

Diplodus vulgaris

Epinephelus marginatus

$\mathrm{G} \quad$ Gymnammodytes cicerelus

$\mathrm{G} \mathrm{T} \quad \mathrm{H}$ Gymnammodytes semisquamatus

G T L TP Helicolenus dactylopterus

G T

Labrus merula

Lichia amia

Lithognathus mormyrus

Lophius boudegassa

G T Lophius piscatorius

G T TP Merluccius merluccius

G Micromesistius poutassou

G T Mola mola

T Mugil cephalus

G T Mullus barbatus

G Mullus surmuletus

Muraena helena

Oblada melanura

Ophidion barbatum

Ophisurus serpens

Pagellus acarne

Pagellus bogaraveo

T L Pagellus erytrhinus

G T L Pagrus pagrus

G Pegusa lascaris

G T L Peristedion cataphractum

G T Phycis phycis

G T Pomatomus saltatrix

Psetta maxima

\begin{tabular}{|c|c|c|c|c|c|c|}
\hline \multicolumn{3}{|l|}{ G } & Sarda sarda & G & & \\
\hline \multicolumn{3}{|l|}{$\mathrm{G}$} & Sardina pilchardus & & $\mathrm{T}$ & $\mathrm{S}$ \\
\hline \multicolumn{3}{|l|}{ G } & Sardinella aurita & G & & \\
\hline \multicolumn{3}{|c|}{ G } & Sarpa salpa & G & $\mathrm{T}$ & \\
\hline \multicolumn{3}{|c|}{$\mathrm{G} T$} & Sciaena umbra & G & $\mathrm{T}$ & \\
\hline \multirow[t]{2}{*}{$\mathrm{G}$} & \multicolumn{2}{|c|}{$\mathrm{T}$} & Scomber japonicus & $\mathrm{G}$ & & \\
\hline & \multicolumn{2}{|c|}{$\mathrm{T}$} & Scomber scombrus & $\mathrm{G}$ & $\mathrm{T} \quad \mathrm{I}$ & $\mathrm{L}$ \\
\hline \multicolumn{3}{|c|}{$\mathrm{G} T$} & Scophthalmus rhombus & G & $\mathrm{T}$ & \\
\hline \multirow[t]{2}{*}{ G } & \multicolumn{2}{|l|}{$\mathrm{T}$} & Scorpaena notata & & $\mathrm{T}$ & $\mathrm{TP}$ \\
\hline & \multirow{2}{*}{\multicolumn{2}{|c|}{$\mathrm{T}$}} & Scorpaena porcus & G & $\mathrm{T} \mathrm{L}$ & $\mathrm{L}$ TP \\
\hline G & & & Scorpaena scrofa & G & $\mathrm{T}$ & \\
\hline \multirow{2}{*}{\multicolumn{2}{|c|}{$\begin{array}{l}G \\
G\end{array}$}} & L TP & Seriola dumerili & G & $\mathrm{T}$ & $\mathrm{L}$ \\
\hline & & $\mathrm{L}$ & Serranus cabrilla & & $\mathrm{T}$ & L TP \\
\hline G & $\mathrm{T}$ & $\mathrm{L}$ & Solea senegalensis & G & $\mathrm{T}$ & \\
\hline $\mathrm{G}$ & $\mathrm{T}$ & $\mathrm{L}$ & Solea solea & G & $\mathrm{T}$ & \\
\hline \multirow[t]{2}{*}{ G } & \multirow{2}{*}{$\begin{array}{l}\mathrm{T} \\
\mathrm{T}\end{array}$} & $\mathrm{L}$ & Sparus aurata & G & $\mathrm{T}$ & $\mathrm{L}$ \\
\hline & & & Sphyraena sphyraena & G & $\mathrm{T}$ & \\
\hline G & $\mathrm{T}$ & L TP & Sphyraena viridensis & & $\mathrm{T}$ & \\
\hline G & & & Spicara maena & G & $\mathrm{T}$ & \\
\hline G & & $\mathrm{L}$ & Spondyliosoma cantharus & $\mathrm{G}$ & $\mathrm{T}$ & \\
\hline & \multirow{2}{*}{$\mathrm{T}$} & $\mathrm{S}$ & Symphodus tinca & & $\mathrm{T}$ & \\
\hline & & $\mathrm{S}$ & Syngnathus acus & & $\mathrm{T}$ & \\
\hline & $\mathrm{T}$ & & Synodus saurus & & $\mathrm{T}$ & \\
\hline & $\mathrm{T}$ & & Trachinus draco & G & $\mathrm{T} \mathrm{I}$ & $\mathrm{L} S$ \\
\hline & $\mathrm{T}$ & & Trachurus trachurus & G & $\mathrm{T} \mathrm{I}$ & $\mathrm{L}$ \\
\hline G & $\mathrm{T}$ & & Trigloporus lastoviza & G & & $\mathrm{L}$ \\
\hline & $\mathrm{T}$ & & Trisopterus minutus & G & $\mathrm{T}$ & \\
\hline G & $\mathrm{T}$ & & Uranoscopus scaber & $\mathrm{G}$ & $\mathrm{T}$ & \\
\hline G & $\mathrm{T}$ & & Xyrichthys novacula & $G$ & & $\mathrm{~L}$ \\
\hline G & & & Zeus faber & & $\mathrm{T}$ & \\
\hline G & & & & & & \\
\hline G & $\mathrm{T}$ & $\mathrm{L}$ & & & & \\
\hline G & $\begin{array}{l}1 \\
\mathrm{~T}\end{array}$ & & & & & \\
\hline & & $\mathrm{TP}$ & & & & \\
\hline G & $\mathrm{T}$ & & & & & \\
\hline & $\mathrm{T}$ & & & & & \\
\hline G & $\mathrm{T}$ & & & & & \\
\hline G & $\mathrm{T}$ & & & & & \\
\hline G & $\mathrm{T}$ & $\mathrm{L}$ & & & & \\
\hline G & $\mathrm{T}$ & $\mathrm{L}$ & & & & \\
\hline & $\begin{array}{l}\mathrm{T} \\
\mathrm{T}\end{array}$ & & & & & \\
\hline G & $\mathrm{T}$ & $\mathrm{L}$ TP & & & & \\
\hline & $\mathrm{T}$ & & & & & \\
\hline
\end{tabular}

dytes cicerelus and G. semisquamatus) and handlining targeting squid Loligo vulgaris, are used only sporadically, so they were excluded from the analysis because they are not representative of the catches and activity of the fishing fleet of L'Estartit.

\section{Identification of métiers}

For the identification of the métiers we followed the methodology used by Katsanevakis et al. (2010), a modification of the multivariate approach by Pelletier and Ferraris (2000). Data on catches were analysed separately, by gear, to identify the different métiers within trammel net, longline and gillnet. Based on set-by-set catch data, principal component analysis (PCA) and cluster analysis were used to obtain homogeneous groups of sets (i.e. métiers). No prior assumptions of the fishery were made, avoiding the inherent subjectivity of qualitative analysis. First, the specific composition of the set catch (weight) was transformed into a landing profile (relative species composition) and data were log-transformed. PCA was based on the covariance matrix of the log-transformed landing profile matrices. The selection of the number of principal components to retain, i.e. those accounting for a large proportion of the total variation of the data, was based on a scree diagram. Thus, the number of métiers within each of the analysed fishing gears and the species which most contributed to a given métier were identified. Occasional species were excluded, i.e. species present in at least $10 \%$ of the gillnet, trammel net or longline sets were retained. Cluster analysis was applied to the log-transformed landing profile matrices (trammel net, longline and gillnet) using Ward's minimum variance clustering algorithm and the Euclidean distance. 


\section{Length frequency distributions/stock status}

The length frequency distributions of the main target species were assessed using all individuals measured in 2004-2005 to show the size ranges exploited by the different artisanal gears used by the small fishing fleet of L'Estartit. The length at maximum yield per recruit $\left(\mathrm{L}_{\mathrm{opt}}\right)$ was estimated for the main target fish species (Mullus surmuletus, Pagellus erythrinus, Sparus aurata, Scorpaena porcus) using the empirical relationships between $\mathrm{L}_{\mathrm{opt}}$ and $\mathrm{L}_{\mathrm{m}}$ (length at first maturity) proposed by Froese and Binohlan (2000). Reproductive load, the proportion of the potential growth span of the species which is covered before maturation $\left(\mathrm{L}_{\text {mat }} / \mathrm{L}_{\text {inf }}\right)$, is provided for these four species. Yield-per-recruit analyses were also run, based on the pseudocohorts, assuming steady state for the fishing in the vicinity of the Medes Islands, using VIT (Lleonart and Salat 1992). Species VBGF parameters $\left(\mathrm{L}_{\text {inf }}(\mathrm{cm}), \mathrm{k}, \mathrm{t}_{0}\right)$ and length-weight parameters ( $\mathrm{L}-\mathrm{W}, \mathrm{a}, \mathrm{b})$ were estimated from sampling data and complemented with parameters from other sources (Arias 1980, Koca 2002, Merino et al. 2008). Input parameters were the following: for striped red mullet, growth parameters $(39.7,0.3,0)$ and L-W parameters $(0.018,3.0)$; for common pandora, growth parameters $(60.0,0.255,-0.04)$ and $\mathrm{L}-\mathrm{W}$ parameters $(0.006,3.040)$; for gilthead seabream, growth parameters $(84.6,0.130,-1.59)$ and $\mathrm{L}-\mathrm{W}$ parameters $(0.014$, $3.0)$; and for black scorpionfish, growth parameters $(40.8,0.11,-2.23)$ and $\mathrm{L}-\mathrm{W}$ parameters $(0.0183,3.02)$. Natural mortality (M) vector was estimated using Probiom (Abella et al. 1997)

\section{RESULTS}

Overall qualitative results of the sampling are presented in Table 1. A total of 109 species were identified in the catches of trammel net, longline, gillnet, traps, handline and "sonsera" (boat seine). Catches included species with high commercial value and discards were

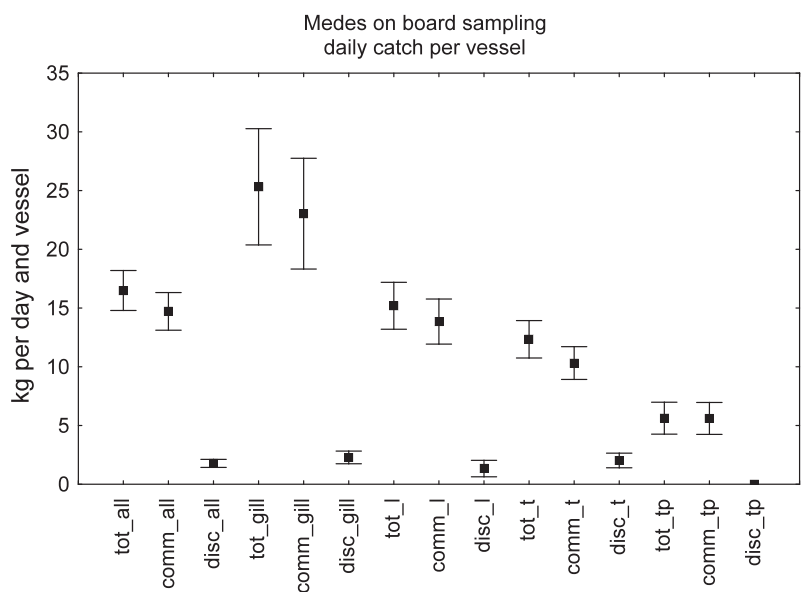

Fig. 2. - Daily catch, in $\mathrm{kg}(\mathrm{kg} \pm \mathrm{se})$ per fishing boat and gear for the total catch (tot), landings (comm) and discards (disc) (n, fishing days; all, gill $+\mathrm{t}+1+\mathrm{tp}, \mathrm{n}=150$; gill, gillnet, $\mathrm{n}=43$; 1 , longline, $\mathrm{n}=44 ; \mathrm{t}$, trammel net, $n=54$; tp, traps, $n=9$ ).
TABLE 2. - Material examined $(\mathrm{kg})$, number of species and sets by fishing gear retained for analyses, and $\%$ in weight of the sampled material that corresponds to the retained species.

\begin{tabular}{lcccc}
\hline & $\begin{array}{c}\text { Sampled } \\
\text { material }(\mathrm{kg})\end{array}$ & $\begin{array}{c}\text { Retained } \\
\text { species }\end{array}$ & Sets & \% weight \\
\hline Gillnet & 982.8 & 24 & 62 & 91 \\
Trammel net & 558.5 & 20 & 65 & 80 \\
Longline & 545.7 & 13 & 56 & 94 \\
\hline
\end{tabular}

very low, or nil, in the case of traps. The daily landings per boat were around $15 \mathrm{~kg}$. Highest daily landings were obtained by gillnet $(23 \mathrm{~kg})$, followed by longline $(14 \mathrm{~kg})$ and trammel net $(10 \mathrm{~kg})$ and traps (5.6 kg) (Fig. 2).
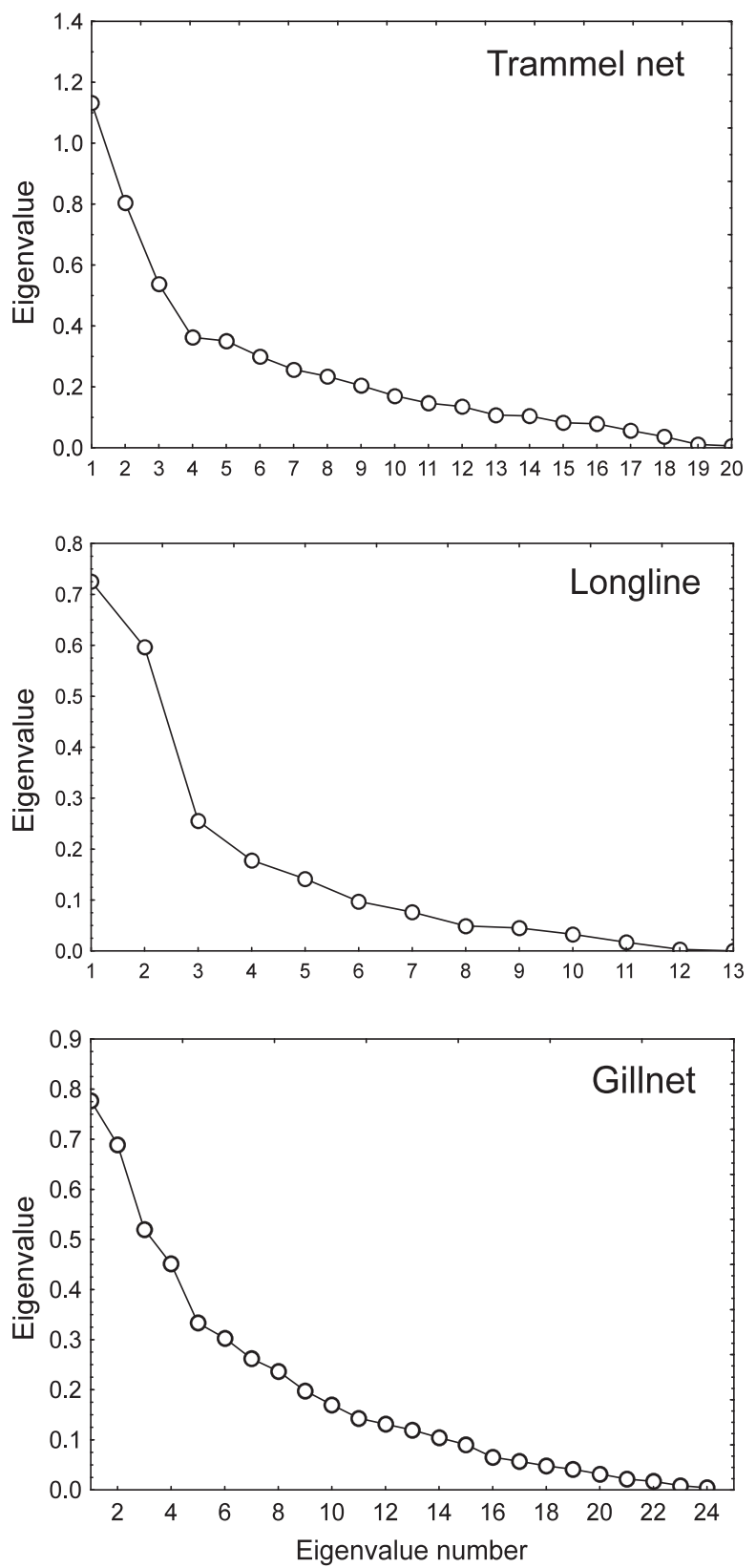

Fig. 3. - Scree diagram for the log-transformed landings profile matrix for trammel net, longline and gillnet. 
TABLE 3. - Species with highest relative contribution to the variance of the identified métiers within trammel net, longline and gillnet (in brackets, the contribution of each métier, in \%, to the total data variance within each fishing gear).

\begin{tabular}{|c|c|c|c|c|c|}
\hline \multicolumn{2}{|l|}{ Trammel net } & \multicolumn{2}{|l|}{ Longline } & \multicolumn{2}{|l|}{ Gillnet } \\
\hline & métier $1(22 \%)$ & & métier $1(33 \%)$ & & métier $1(16 \%)$ \\
\hline Sepia officinalis & 0.29 & Sparus aurata & 0.85 & Merluccius merluccius & 0.43 \\
\hline Palinurus elephas & 0.19 & Conger conger & 0.05 & Sparus aurata & 0.26 \\
\hline Scorpaena scrofa & 0.11 & & & Citharus linguatula & 0.08 \\
\hline Solea solea & 0.10 & & métier $2(27 \%)$ & Pagellus bogaraveo & 0.05 \\
\hline & & Dicentrarchus labrax & 0.86 & & \\
\hline Mullus surmuletus & $\begin{array}{c}\text { métier } 2(16 \%) \\
0.37\end{array}$ & Conger conger & 0.06 & & $\begin{array}{c}\text { métier } 2(14 \%) \\
0.76\end{array}$ \\
\hline Palinurus elephas & 0.14 & Pagellus erythrinus & 0.06 & $\begin{array}{l}\text { Pagellus erytnrinus bogaraveo } \\
\text { Pagello }\end{array}$ & 0.05 \\
\hline Pagellus bogaraveo & 0.14 & & métier $3(11 \%)$ & Sarda sarda & 0.05 \\
\hline Solea solea & 0.12 & $\begin{array}{l}\text { Pagellus erythrinus } \\
\text { Dicentrarchus labrax }\end{array}$ & $\begin{array}{l}0.70 \\
0.08\end{array}$ & & métier $3(11 \%)$ \\
\hline & métier $3(10 \%)$ & Conger conger & 0.07 & Sarda sarda & 0.22 \\
\hline Solea solea & 0.37 & Pagrus pagrus & 0.06 & Lithognathus mormyrus & 0.21 \\
\hline Dicentrarchus labrax & 0.16 & & & Uranoscopus scaber & 0.12 \\
\hline Phycis phycis & 0.12 & & & Phycis phycis & 0.08 \\
\hline & métier $4(7 \%)$ & & & & métier 4 (9\%) \\
\hline Scorpaena porcus & 0.25 & & & Sparus aurata & 0.42 \\
\hline Phycis phycis & 0.21 & & & Sarda sarda & 0.29 \\
\hline Lithognathus mormyrus & 0.20 & & & Merluccius merluccius & 0.12 \\
\hline & & & & & métier $5(7 \%)$ \\
\hline & & & & Sarda sarda & 0.19 \\
\hline & & & & Scorpaena scrofa & 0.15 \\
\hline & & & & Phycis phycis & 0.15 \\
\hline & & & & Lophius piscatorius & 0.13 \\
\hline & & & & Pagellus bogaraveo & 0.12 \\
\hline & & & & Dentex dentex & 0.10 \\
\hline
\end{tabular}

\section{Identification of métiers}

Input data for the analyses are summarized in Table 2. Four métiers were identified in trammel net, three in longline and five in gillnet. The scree diagrams for the log-transformed landing profile matrix for trammel net, longline and gillnet and the species with highest relative contribution to the variance of the métiers within each fishing gear are presented in Figure 3 and Table 3. Taking into account that the number of boats was small and that the time that the sets are in the water depends on the target species within a given métier, the characteristics of the nets and longlines remained fairly constant.

The scree diagram for the trammel net catch profile matrix suggests retaining four factors, which accounted for $55 \%$ of the data variance (Fig. 3, Table 3). Figure 4 shows the four métiers identified through cluster analysis. The species characteristics of métier 1 were common cuttlefish (Sepia officinalis) and spiny lobster (Palinurus elephas), with a relative contribution to the variance of these two species of around 50\%, largescaled scorpion fish (Scorpaena scrofa) and common sole (Solea solea), each one contributing around $10 \%$. Most of the sets that made up métier 1 were soaked at 15-60 m depth over rock and gravel bottoms. Striped red mullet (Mullus surmuletus) was the target species of métier 2, with a relative contribution to the variance of the métier of $37 \%$; other species identified in this métier were Palinurus elephas, blackspot seabream (Pagellus bogaraveo) and Solea solea. Métier 2 included two groups, one with sets soaked at a depth of
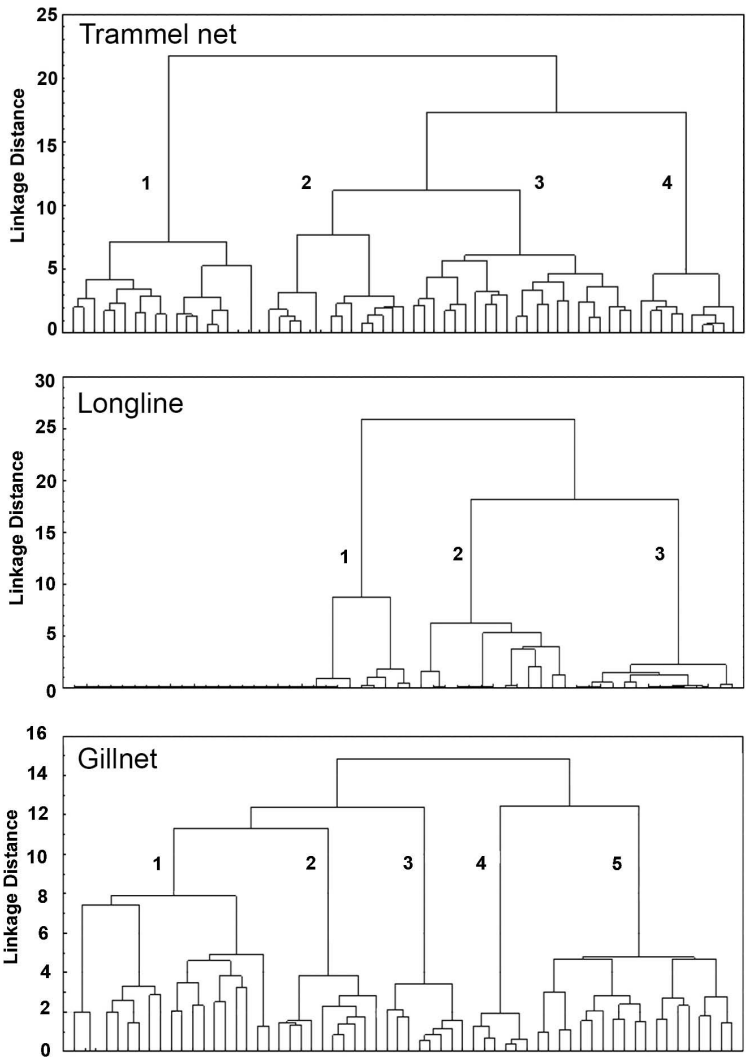

Fig. 4. - Métiers identified within trammel net, longline and gillnet through cluster analysis applied to the log-transformed landing profile matrices using Ward's minimum variance clustering algorithm and the Euclidean distance. 

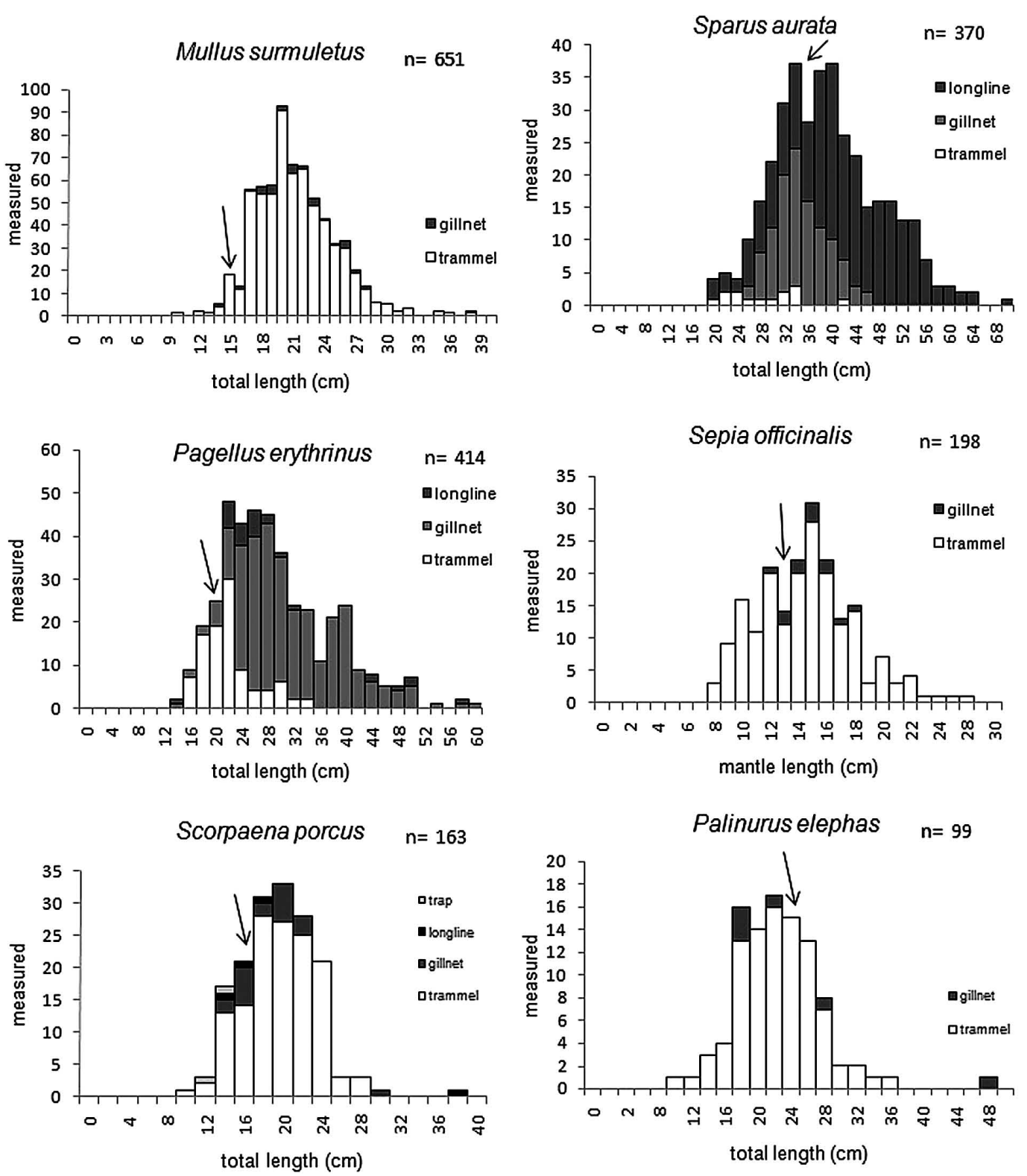

Fig. 5. - Length-frequency distributions of striped red mullet (Mullus sumuletus), common pandora (Pagellus erythrinus), gilthead seabream (Sparus aurata), black scorpionfish (Scorpaena porcus), cuttlefish (Sepia officinalis) and spiny lobster (Palinurus elephas) (all specimens measured 2004-2005, by gear; the arrow indicates the size at first maturity).

less than $10 \mathrm{~m}$ on sandy bottoms in spring, and a second one with sets over mud and gravel bottoms at 45 $70 \mathrm{~m}$ depth. The target species of métier 3 was Solea solea, with a relative contribution to the variance of the metier of $37 \%$. Other species characteristics of métier 3 were seabass (Dicentrarchus labrax) and forkbeard (Phycis phycis). This cluster consisted of sets soaked over sandy bottoms at shallow waters, half of them at less than $6 \mathrm{~m}$ depth. As for métier 4, three species contributed similarly to the relative variance: black scorpionfish (Scorpaena porcus), forkbeard Phycis phycis and striped seabream (Lithognathus mormyrus). This métier included summer sets over a variety of bottoms, mostly sandy bottoms, but also rocky and rocky-gravel, at 20-30 $\mathrm{m}$ depth.
Three factors were retained within longline, which accounted for $71 \%$ of the data variance (Figs. 3 and 4 , Table 3). Most of the sets were set over sandy bottoms, from less than $10 \mathrm{~m}$ depth to $20 \mathrm{~m}$ depth. In this gear, the target species of each métier were clearly identified: gilthead seabream (Sparus aurata; métier 1), Dicentrarchus labrax (métier 2) and common pandora (Pagellus erythrinus; métier 3). Most of the métier 1 sets were from spring and summer; those of métier 2 included also autumn sets; and métier 3 sets included also spring to autumn sets, some of them soaked over sea grass.

In general, gillnet sets were soaked in deeper waters than trammel net. Within gillnet, the scree diagram suggests retaining five factors, which accounted 
for $57 \%$ of the data variance (Figs. 3 and 4, Table 3 ). The target species of métier 1 was hake (Merluccius merluccius). This group included sets soaked over different types of bottom (sand, sand and gravel, gravel, mud, mud and gravel), from spring to autumn, at a depth ranging from less than $20 \mathrm{~m}$ to more than $50 \mathrm{~m}$. Pagellus erythrinus was the target species of métier 2 (76\% of the relative variance), which included only autumn sets over muddy and muddy and gravel bottoms, between 20 and $60 \mathrm{~m}$ depth. Métier 3 grouped sets also of the autumn months, at similar depths and bottoms to those of métier 2, and the target species were the Atlantic bonito (Sarda sarda) and striped seabream Lithognathus mormyrus. Métier 4, with Sparus aurata and Sarda sarda as characteristic species, was made up of sets soaked at a depth of 70-80 $\mathrm{m}$ in autumn. Regarding métier 5, a number of species each contributed to a relative small proportion of the relative variance of the factor; these included Sarda sarda, Scorpaena scrofa and Phycis phycis. The sets under this métier were mostly soaked over sandy-muddy bottoms, but also on gravel, and rock and gravel bottoms, mainly in autumn. Sarda sarda appeared in three of the five gillnet métiers, either as the main target or among the species characterizing the métier.

\section{Length frequency distributions/stock status}

As a whole, most of the catch consisted of mature individuals and the presence of very large individuals is worth mentioning. The length-frequency distributions of Mullus surmuletus, Pagellus erythrinus, Sparus aurata, Scorpaena porcus, Sepia officinalis and Palinurus elephas, by gear, are presented in Figure 5. The size distributions clearly show the size range exploited by the different fishing gears targeting a given species. In the fishery under study the interaction between different gears was especially noteworthy in the case of common pandora and gilthead seabream. The dusky grouper (Epinephelus marginatus), an emblematic species that is at present rather uncommon on the Catalan Coast, was captured only twice during the whole sampling period, in the buffer area in May and July 2005, with longline $(87 \mathrm{~cm}$ total length) and gillnet $(82 \mathrm{~cm}$ total length) at $30-40 \mathrm{~m}$ depth. The exception to very large individuals of most species present in the catches was Palinurus elephas. In this case most of the catch consisted of juveniles, part of them caught in the buffer area surrounding the marine reserve, but most of them captured at a certain distance from the marine reserve ( 3 to $15 \mathrm{~km}$ from the reserve).

The estimated length at maximum yield per recruit $\left(\mathrm{L}_{\mathrm{opt}}\right)$ for striped red mullet, common pandora, gilthead seabream and black scorpionfish was in all four cases slightly larger than the size at first maturity (Table 4). Interestingly, the catch mean length was much greater than both the length at first maturity and $\mathrm{L}_{\text {opt }}$. The current yield per recruit $\left(Y / R_{c}\right)$ were close to the maxi-
TABLE 4. - Length at maximum yield per recruit $\left(\mathrm{L}_{\text {opt }}\right)$ estimated from the size at first maturity $\left(\mathrm{L}_{\text {mat }}\right)$, as proposed by Froese and Biohlan (2000), mean catch length $\left(\mathrm{L}_{\text {mean }}\right)$ and reproductive load $\left(\mathrm{L}_{\text {mat }} / \mathrm{L}_{\text {inf }}\right)$; total length in $\mathrm{cm}$.

\begin{tabular}{lcccc}
\hline & $\mathrm{L}_{\mathrm{mat}}$ & $\mathrm{L}_{\mathrm{opt}}$ & $\mathrm{L}_{\text {mean }}$ & $\left(\mathrm{L}_{\mathrm{mat}} / \mathrm{L}_{\mathrm{inf}}\right)$ \\
\hline Mullus surmuletus & 15 & 15.2 & 21.7 & 0.4 \\
Pagellus erythrinus & 20 & 20.6 & 31.2 & 0.3 \\
Sparus aurata & 34 & 36.0 & 42.2 & 0.4 \\
Scorpaena porcus & 17 & 17.3 & 20.6 & 0.4 \\
\hline
\end{tabular}

TABLE 5. - Summary of the yield-per-recruit results: current status $\left(\mathrm{Y} / \mathrm{R}_{\mathrm{c}}\right), \mathrm{Y} / \mathrm{R}_{\max }$ and $\mathrm{Y} / \mathrm{R}$ at $\mathrm{F}_{(0.1)}\left(\mathrm{Y} / \mathrm{R}_{(0.1)}\right)$; values in $\mathrm{g}$.

\begin{tabular}{lccc}
\hline & $\mathrm{Y} / \mathrm{R}_{\mathrm{c}}$ & $\mathrm{Y} / \mathrm{R}_{\max }$ & $\mathrm{Y} / \mathrm{R}_{(0.1)}$ \\
\hline Mullus surmuletus & 50 & 64 & 60 \\
Pagellus erythrinus & 377 & 378 & 363 \\
Sparus aurata & 546 & 571 & 547 \\
Scorpaena porcus & 54 & 55 & 48 \\
\hline
\end{tabular}

mum $\mathrm{Y} / \mathrm{R}$ and $\mathrm{Y} / \mathrm{R}$ at $\mathrm{F}_{(0.1)}$. In all cases these results suggest that none of the species can be considered over-exploited (Table 5).

\section{DISCUSSION}

Artisanal fishing is an activity profoundly rooted in Mediterranean customs and traditions. However, in the last few decades a general decrease in smallscale fishery in the Mediterranean is taking place, as elsewhere in Europe. The disappearance of artisanal fishing is mainly due to its low economic competitiveness in relation to other coastal activities (tourism) and competition for resources with large-scale fleets or recreational fishing. The reduction of this activity entails the loss of important social values, such as traditional knowledge and locally-rooted jobs (Gómez et al. 2006, Guyader 2007).

Small-scale Mediterranean fisheries are highly complex and multi-species (Jabeur et al. 2000, Belcari et al. 2002, Colloca et al. 2004, Tzanatos et al. 2005, Moranta et al. 2008, Caddy 2009, Forcada et al. 2010). The métiers identified in this study are common all around the Mediterranean (e.g. trammel net targeting either cuttlefish, striped red mullet or common sole; longline targeting gilthead seabream; gillnet targeting hake, common pandora or Atlantic bonito). In some cases, the métier was clearly characterized by a single target species, but in others the catch of the métier was characterized by more species (Table 3 ). However, the pool of target species in the fishery studied is small considering the large variety of fishing targets and techniques used within the small-scale Mediterranean fisheries. The Medes Islands artisanal fishery is certainly of small dimension in terms of both number of fishing vessels and fishing area.

When an alternative to fishing is available, such as tourism-related activities derived from the existence of the marine reserve, fishermen often take this opportunity. The fishing effort applied in the area around the 
Medes Islands was lower than allowed by the fishing regulations. Only 7 vessels out of the 24 that made up the fishing fleet of L'Estartit at the time of sampling went fishing all year round and the length of trammels nets and longline was smaller than permitted. The activity is conditioned by the weather and tourism, and is carried out around 120 days during the year. As a matter of fact, the highest effort is not coincidental with the time of the year when weather conditions are best for fishing (summer) because fishermen shift to tourismrelated activities.

Overall daily landings were lower than those reported in other areas for similar fisheries (e.g. GarcíaRodríguez et al. 2006). However, as evidenced from both the fishing targets, which include the most valued species, and the exploited sizes, the fishing around Medes is highly selective. In five of the six examples presented on the distribution of sizes (striped red mullet, common pandora, gilthead seabream, black scorpionfish and common cuttlefish), most of the catch consisted of mature individuals. For the same fishing techniques and for the fish species, these exploited sizes are much larger than those reported in other Mediterranean areas which are not under the influence of a marine reserve (Martín et al. 1999, Stergiou and Erzini 2002, Tzanatos et al. 2008), and similar in the case of cuttlefish (Belcari et al. 2002, Fabi and Grati 2005). The larger sampled sizes of striped red mullet, common pandora, gilthead seabream and black scorpionfish (Fig. 5) were well beyond different estimations of $\mathrm{L}_{\mathrm{inf}}$ proposed for the species in the Mediterranean (cf. www.fishbase.com and references therein). Although one of the identified métiers was gillnet targeting hake, a major fishing resource within the Mediterranean, the size distribution of hake is not presented because, taking into account the biology of the species and the different environments where the species can be found during its life cycle (typically deeper than $60 \mathrm{~m}$ depth), it cannot be considered to be a response to protection because the fisheries in the study area are strictly coastal and only occasionally reach areas where hake is distributed.

Marine reserves have been demonstrated to have clear effects on the surrounding fisheries, especially on the large fished species (Molloy et al. 2009, Babcock et al. 2010, Vandeperre et al. 2010). In the fishery under study most of the landings consisted of mature individuals. Catches were made up of very large individuals, with the catch mean length greatly exceeding $\mathrm{L}_{\text {opt }}$, the mean length at maximum yield per recruit. No signs of overexploitation were apparent from the results of the yield per recruit analysis performed for Mullus surmuletus, Pagellus erythrinus, Sparus aurata and Scorpaena porcus, based on pseudocohort analysis. Steady state was assumed, which may not be the case for this fishery, because fishing effort, in terms of number of fishing vessels, has undergone a steady decrease (from 37 registered in 1990 to 24 at the time of sampling). However, the results of these analyses along with the distributions of the exploited sizes, with presence of very large sizes, suggest a situation of low fishing pressure. Striped red mullet and common pandora have recently been assessed in other Mediterranean areas. In the Balearic Islands (Quetglas et al. 2010) and in the Tyrrhenian Sea (Cardinale et al. 2011), the status of Mullus surmuletus stocks was defined as over-exploited on the basis of yield-perrecruit analysis. Yield-per-recruit results in these areas were much lower than those estimated for the Medes Islands. In the Balearic Islands, for instance, striped red mullet is fished by bottom trawl and trammel net and yield-per-recruit results were $\mathrm{Y} / \mathrm{R}_{\mathrm{c}}=16.06 \mathrm{~g}, \mathrm{Y} / \mathrm{R}_{\max }=$ $16.15 \mathrm{~g}$, and $\mathrm{Y} / \mathrm{R}_{(0.1)}=15.03 \mathrm{~g}$. In the Tyrrhenian Sea, where Mullus surmuletus is fished by bottom trawl, gillnet and trammel net, the yield-per-recruit results were $Y / R_{c}=43.4 \mathrm{~g}, Y / R_{\max }=46.9 \mathrm{~g}$, and $\mathrm{Y} / \mathrm{R}_{(0.1)}=45.4$ $\mathrm{g}$ (see Table 5 for comparison). In the Tyrrherian Sea common pandora is mainly caught by the trawlers operating near the shore and also by small-scale fisheries. The bulk of the catch falls within the range $14-21 \mathrm{~cm}$, with a peak at $17-18 \mathrm{~cm}$. This stock was assessed as over-exploited (Cardinale et al. 2011). Because of the different methodologies used, the results are not comparable with our study. However, the exploitation in the Tyrrhenian Sea is based on sizes much smaller than those exploited at the Medes Islands (Fig. 5).

Babcock et al. (2010), in their analysis on decadal trends in marine reserves, unveiled differential timing for the direct and indirect effect of protection to be detected. They found the time to initial detection of direct effects on the fishing target species to be $5.13 \pm 1.9$ years. Indeed, García-Rubies and Zabala (1990), six years after the prohibition of fishing in Medes Islands, found the size structure of vulnerable species to be different at the reserve sites to that in the unprotected areas, with the modal size classes larger in the reserve. Moreover, the authors emphasized that some highly vulnerable species, such as Epinephelus marginatus and Sciaena umbra, had been found only in the reserve, while others, such as Sparus aurata and Dicentrarchus labrax, were much more frequent inside the reserve. Higher fish species richness and larger individuals inside the reserve have also been reported in another protected area very close to the Medes Islands, Ses Negres (established in 1993, $5 \mathrm{~km}$ south of the Medes Islands, $1.3 \mathrm{~km}$ of rocky coastline protected from the shore to $40 \mathrm{~m}$ depth; Rius 2007). In this case the refuge effect was apparent only four years after the creation of the reserve.

The presence of large individuals inside the Medes Islands reserve suggests that the protected area acts as refuge for large spawners, so it has the potential to export fish eggs and larvae. Reproductive load falls generally between 0.4 and 0.9 (Froese and Binholan 2000). At the Medes Islands, the reproductive load of red mullet, common pandora, gilthead seabream and black scorpionfish appears to be in the lower limit of this range, or even lower values. Ichthyoplankton stud- 
ies covering the area of the Medes Islands where the fishing fleet operates carried out in spring and summer 2003 highlighted the overlap between species found at larval stage and as adults in commercial catches. Among them are some of the main fishing targets, Mullus surmuletus, Pagellus erythrinus, Sarda sarda, Dicentrarchus labrax and Epinephelus marginatus. Furthermore, the high abundance of coastal fish species larvae in the marine reserve must be related to the high abundance of adults and a possible retention of larvae (Sabatés et al. 2003, López-Sanz et al. 2009, 2011). López-Sanz et al. 2011 also provided evidence of larval export of three commercial species affected by the reserve (Epinephelus marginatus, Pagellus erythrinus and Scorpaena porcus).

The standard biological monitoring around the Medes Islands may also contribute to regional assessments of exploited populations. In the context of the EC Marine Strategy Framework Directive (Directive 2008/56/EC), the good environmental status is based on 11 descriptors, dealing with ecosystem characteristics and functioning and the effect of anthropogenic activities on the environment. For instance, descriptor 1 refers to biological diversity, descriptor 3 refers to the status of commercially exploited populations, and descriptor 4 refers to marine food webs. These regional assessments could take advantage of a strong local knowledge base.

Inside the integral reserve the extraction of living organisms is forbidden, affording complete protection to the rocky substratum and Posidonia oceanica beds of the surrounding bottoms. The colonies of red coral (Corallium rubrum), key ecosystem engineering species of Mediterranean coralligenous assemblages, are older and larger than in harvested areas (Tsounis et al. 2006). However, marine reserves can also have adverse effects for some species. Cascading effects caused by the prohibition of fishing that have been demonstrated in the Medes Islands integral reserve include a decrease in European spiny lobster Palinurus elephas (Díaz et al. 2005) and sea urchin Paracentrotus lividus (Hereu et al. 2005) and higher natural mortality in some fish species (Macpherson et al. 2000). In the case of spiny lobster, increased predation by fish of juvenile phases of lobster within the protected area has been reported (Díaz et al . 2005); this finding is supported by the results of this study, in which most of the spiny lobster juveniles were not caught close to the reserve.

Spill-over from marine reserves of the characteristics of the Medes Islands (small, rocky, coastal reserve), evidenced by a local concentration of fishing effort around the borders, has been demonstrated to occur within a few hundreds of metres around the protected areas and to be related to the distribution of habitats inside and around the protected area (Stelzenmüller et al. 2007, 2008, Harmelin-Vivien et al. 2008, Forcada et al. 2009). Halpern and Warner (2003) argue that a single general design of a network of reserves of moderate size and variable spacing can meet the needs and goals of most stakeholders interested in marine resources, but if biomass export from marine reserves takes place at small spatial scales, Mediterranean reserves may be too far apart to act as a network at regional scale (Claudet et al. 2008). Stelzenmüller et al. (2009) confirmed empirically on a local scale that the conservation of diversity by a marine protected area with fishing regulations and the preservation of habitat can lead to fisheries benefits and pointed out that biological conservation and fisheries benefits can be complementary in the long term. Furthermore, the existence of the reserve has generated a great deal of economic activity linked to the many tourists that go to Medes Islands (around 220000 per year) from which the population living close to the reserve directly benefit (Merino et al. 2009).

\section{ACKNOWLEDGEMENTS}

We acknowledge the cooperation of the Fishermen's Association of L'Estartit and the director of the Medes Islands Marine Reserve, Nuria Muñoz. The study was partially funded by the European Commission research projects BIOMEX (QLRT-2001-00891) and EMPAFISH (STREP/006539).

\section{REFERENCES}

Abella A., Caddy J., Serena F. 1997. Do natural mortality and availability decline with age? An alternative yield paradigm for juvenile fisheries, illustrated by the hake Merluccius merluccius fishery in the Mediterranean. Aquat. Living Resour. 10: 257-269.

Arias A. 1980. Crecimiento, régimen alimentario y reproducción de la dorada (Sparus aurata L.) y del róbalo (Dicentrarchus labrax L.) en los esteros de Cádiz. Inv. Pesq. 44: 59-83.

Babcock R.C., Shears N.T., Alcala A.C., Barrett N.S., Edgar G.J., Lafferty K.D., McClanahan T.R., Russ G.R. 2010. Decadal trends in marine reserves reveal differential rates of change in direct and indirect effects. PNAS 107 (43): 18256-18261.

Ballester A. 1971. Proyecto para el establecimiento de un ParqueReserva Submarino en las Islas Medas. Inmersión y Ciencia 3: 7-33.

Belcari P., Sartor P., Sánchez P., Demestre M., Tsangridis A., Leondrakis P., Lefkaditou E., Papaconstantinou C. 2002. Exploitation patterns of the cuttlefish, Sepia officinalis (Cephalopoda, Sepiidae) in the Mediterranean Sea. Bull. Mar. Sci. 71: 187-192.

Caddy J.F., 2009. Practical issues in choosing a framework for resource assessment and management of Mediterranean and Black Sea fisheries. Med. Mar. Sci. 10(1): 83-119

Cardinale M., Rätz H.-J., Charef A. (Eds.) 2011. Scientific, Technical and Economic Committee for Fisheries (STECF). Assessment of Mediterranean Sea stocks - part 2 (STECF-11-14). EUR - Scientific and Technical Research series - ISSN 1018-5593.

Claudet J., Pelletier D., Youvenel J.-Y., Bachet F., Galzin R. 2006. Assessing the effects of marine protected area (MPA) on a reef fish assemblage in a northwestern Mediterranean marine reserve: Identifying community- based indicators. Biol. Conserv. 130: $349-369$

Claudet J., Osenberg C.W., Benedetti-Cecchi L., Domenici P., García- Charton J.A. Pérez-Ruzafa A., Badalamenti F., BayleSempere J., Brito A., Bulleri F., Culioli J.M., Dimech M., Falcón J.M., Guala I., Milazzo M., Sánchez-Meca J., Somerfield P.J., Stobart B., Vandeperre F., Valle C., Planes S. 2008. Marine reserves: size and age do matter. Ecol. Lett. 11: 481-489.

Colloca F., Crespi V., Cerasi S., Coppola S.R. 2004. Structure and evolution of the artisanal fishery in a southern Italy coastal area. Fish. Res. 69: 359-369. 
Díaz D., Zabala M., Linares C., Hereu B., Abelló P. 2005. Increased predation of juvenile European spiny lobster (Palinurus elephas) in a marine protected area. NZ J. Mar. Freshw. Res. 39: 447-453.

Directive 2008/56/EC of the European Parliament and the Council of 17 June 2008 establishing a framework for the community action in the field of marine environmental policy (Marine Strategy Framework Directive). Official Journal EU of 25.06.2008, L164/19-40.

European Commission. 2010. Facts and figures on the Common Fisheries Policy - Basic statistical data, 2010 Edition. Luxembourg, Publications Office of the European Union. DOI: $10.2771 / 12708$

Fabi G., Grati F. 2005. Small-scale fisheries in the maritime department of Ancona (Central Northern Adriatic Sea). AdriaMed Tech. Doc. No.15: 64-84.

Forcada A., Valle C., Bonhomme P., Criquet G., Cadiou G., Lenfant P., Sánchez-Lizaso J.L. 2009. Effects of habitat on spillover from marine protected areas to artisanal fisheries. Mar. Ecol. Prog. Ser. 379: 197-211.

Forcada A., Valle C., Sánchez-Lizaso J.L., Bayle-Sempere J.T., Corsi F. 2010. Structure and spatio-temporal dynamics of artisanal fisheries around a Mediterranean marine protected area. ICES J. Mar. Sci. 67: 191-203.

Francour F., Harmelin J.G., Pollard D., Sartoretto S. 2001. A review of marine protected areas in the northwestern Mediterranean region: siting, usage, zonation and management. Aquatic Conser: Mar. Freshw. Ecosyst. 11: 155-188.

Froese R., Binohlan C. 2000. Empirical relationships to estimate asymptotic length, length at first maturity and length at maximum yield per recruit in fishes, with a simple method to evaluate length frequency data. J. Fish. Biol. 56: 758-773.

García-Rodríguez M., Fernández A.M., Esteban A. 2006. Characterization, analysis and catch rates of the small-scale fisheries of the Alicante Gulf (SE Spain) over a 10 years time series. Fish. Res. 77: 226-238.

García- Rubies A., Zabala M. 1990. Effects of total fishing prohibition on the rocky fish assemblages of Medes Islands marine reserve (NW Mediterranean). Sci. Mar. 54: 317-328.

Generalitat de Catalunya. 2008. Pla Rector d'Ús i Gestió de l'Àrea Protegida de les Illes Medes. Departament de Medi Ambient i Habitatge. http://www20.gencat.cat/portal/site/parcsnaturals/ menuitem.1eb639065e10cdb0e6789a10b0c0e1a0/?vgnexto $\mathrm{id}=518 \mathrm{afa} 714 \mathrm{~d} 0 \mathrm{c} 2210 \mathrm{VgnVCM} 1000008 \mathrm{~d} 0 \mathrm{c} 1 \mathrm{e} 0 \mathrm{aRCRD} \& \mathrm{v}$ gnextchannel=518afa714d0c2210VgnVCM1000008d0c1e0 aRCRD\&vgnextfmt $=$ defaul

Gómez S., Lloret J., Demestre M. 2006. The decline of the Artisanal Fisheries in the Mediterranean Coastal Areas: The Case of Cap de Creus (Cape Creus). Coast. Manage. 34: 217-232.

Guyader O. (coord.) 2007. Small-Scale Coastal Fisheries in Europe, Final report of the contract No FISH/2005/10, 447 pp. http:// archimer.ifremer.fr/doc/2007/rapport-6348.pdf

Halpern B.S., Walter R.R. 2003. Matching marine reserve design to reserve objectives. Proc. R. Soc. Lond. B 270: 1871-1878. DOI 10.1098/rspb.2003.2405

Harmelin-Vivien M., Le Diréach L., Bayle-Sempere J., Charbonnel E., García-Charton J.A., Ody D., Pérez-Ruzafa A., Reñones O., Sánchez-Jerez P., Valle C. 2008. Gradients of abundance and biomass across reserve boundaries in six Mediterranean marine protected areas: Evidence of fish spillover? Biol. Conserv. 141: 1829-1839.

Hereu B., Zabala M., Linares C. 2005. The effects of predator abundance and habitat structural complexity on survival of juvenile sea urchins. Mar. Biol. 146: 293-299.

Hereu B., Díaz D., Pasqual J., Zabala M., Sala E. 2006. Temporal patterns of spawning of the dusky grouper Epinephelus marginatus in relation to environmental factors. Mar. Ecol. Prog. Ser. 325: 187-194.

Holland, D.S. 2000. A bioeconomic model of marine sanctuaries on Georges Bank. Can. J. Fish. Aquat. Sci., 57: 1307-1319.

Holland, D.S., Bentley N., Lallemand, Ph. 2005. A bioeconomic analysis of management strategies for rebuilding and maintenance of the NSS rock lobster (Jasus edwardsii) stock in southern New Zealand. Can. J. Fish. Aquat. Sci., 62: 1553-1569.

Jabeur Ch., Gobert B., Missaoui H. 2000. Typologie de la flottille de pêche côtière dans le golfe de Gabès (Tunisie). Aquat. Living Resour. 13: 421-428
Katsanevakis S., Maravelias Ch.D., Kell L.T. 2010. Landings profiles and potential métiers in Greek set longliners. ICES J. Mar. Sci. 67: 646-656.

Koka H.U. 2002. A study on the determination of some parameters of the scorpionfish (Scorpaena porcus Linne., 1758) caught by bottom nets in the area of Sinop. Turk. J. Vet. Anim. Sci. 26: 65-69.

Lleonart, J. 1990. La pesquería de Cataluña y Valencia: descripción global y planteamiento de bases para su seguimiento. Final Report. EC DG XIV Ref. No 1989/3.

Lleonart J., Salat J. 1992. VIT Programa de Análisis de Pesquerías. Inf. Téc. Sci. Mar. 168-169.

López-Sanz A., Vert N., Zabala M., Sabatés A. 2009. Small-scale distribution of fish larvae around the Medes Islands marine protected area (NW Mediterranean). J. Plankton Res. 31: 763-775.

Lopez-Sanz A., Stelzenmüller V., Maynou F., Sabatés A. 2011. The influence of environmental characteristics on fish larvae spatial patterns related to a Marine Protected Area: the Medes islands (NW Mediterranean). Est. Coast. Shelf Sci. 92: 521-533.

Macpherson E., García-Rubies A., Gordoa A. 2000. Direct estimation of natural mortality rates for littoral marine fishes using populational data from a marine reserve. Mar. Biol. 137: 1067-1076.

Martín P., Sartor P., García-Rodríguez. 1999. Exploitation patterns of the European hake Merluccius merluccius, red mullet Mullus barbatus and striped red mullet Mullus surmuletus in the western Mediterranean. J. Appl. Ichthyol. 15: 24-28.

Merino G., Morales-Nin B., Maynou F., Grau A.M. 2008. Assessment and bioeconomic analysis of the Majorca (NW Mediterranean) trammel net fishery. Aquat. Living Resour. 21: 99-107.

Merino G., Maynou F., Boncoeur J. 2009. Bioeconomic model for a three-zone Marine Protected Area: a case study of Medes Islands (northwest Mediterranean). ICES J. Mar. Sci. 66: 147-154.

Molloy P., McLean I., Côté I. 2009. Effects of marine reserve age on fish populations: a global meta-analysis. J. Appl. Ecol. 46: 743-751.

Moranta J., Quetglas A., Massutí E., Guijarro B., Ordines F., Valls M. 2008. Research trends on demersal fisheries oceanography in the Mediterranean. In: Rades CV, Tilesman EB (eds.) Advances in Environmental Research, Volume 1. Nova Science Publishers, New York, pp. 1-57.

Pelletier D., Ferraris J. 2000. A multivariate approach for defining fishing tactics from commercial catch and effort data. Can. J. Fish. Aquat. Sci. 57: 51-65.

Quetglas A., Ordines F., González N. 2010. General Fisheries Commission for the Mediterranean. SAC SCSA. WG on Stock Assessment on Demersal Species. Stock Assessment Forms (http://151.1.154.86/GfcmWebSite/SAC/2010/SCSA_WG Demersal_Species/SAF/2010_MUR_GSA05_IEO.pdf)

Rius M. 2007. The effect of protection on fish populations in the Ses Negres Marine Reserve (NW Mediterranean, Spain). Sci. Mar. 71: 499-204.

Sabatés A., Zabala M., García-Rubies A. 2003. Larval fish communities in the Medes Islands Marine Reserve (North-west Mediterranean). J. Plankton Res. 25: 1035-1046.

Stelzenmüller V., Maynou F., Bernard G., Cadiou G., Camilleri M., Crec'hriou R., Criquet G., Dimech M., Esparza O., Higgings R., Lenfant Ph., Pérez-Ruzafa A. 2008. Spatial assessment of fishing effort around European marine reserves: Implications for successful fisheries management. Mar. Pollut. Bull. 56: 2018-2026.

Stelzenmüller V., Maynou F., Martín P. 2007. Spatial assessment of benefits of a coastal Mediterranean Marine Protected Area. Biol. Conserv. 136: 571-583.

Stelzenmüller V., Maynou F., Martín P. 2009. Patterns of species and functional diversity around a coastal marine reserve: a fisheries perspective. Aquatic Conser: Mar. Freshw. Ecosyst. 19: 554-565.

Stergiou K.I., Erzini K. 2002. Comparative fixed gear studies in the Cyclades (Aegean Sea): size selectivity of small-hook longlines and monofilament gill nets. Fish. Res. 58: 25-40.

Tsounis G., Rossi S., Gili J.-M., Arntz W. 2006. Population structure of an exploited benthic cnidarian: the case study of red coral (Corallium rubrum L.). Mar. Biol. 149: 1059-1070.

Tzanatos E., Dimitriou E., Katselis G., Georgiadis M., Koutsikopoulos C. 2005. Composition, temporal dynamics and regional characteristics of small-scale fisheries in Greece. Fish. Res. 73: $147-158$. 
Tzanatos E., Somarakis S., Tserpes G., Koutsikopoulos C. 2008. Catch length analysis, relation to minimum landing sizes and management implications from a Mediterranean small-scale fishery (Patraikos Gulf, Greece). Fish. Res. 93: 125-134.

Vandeperre F., Higgins R., Santos R.S., Marcos C., Pérez- Ruzafa A. (Coord.). 2008. Fishery Regimes in Atlanto- Mediterranean European Marine Protected Areas. EMPAFISH Project, Booklet No 2. Editum. 108 pp. ISBN 978-84-8371-724-0.

Vandeperre F., Higgings R., Sánchez-Meca J., Maynou F., Goñi R., Martín-Sosa P., Pérez-Ruzafa A., Afonso P., Betocci I.,
Crec'hriou R., D'Anna G., Dimech M., Dorta C., Esparza O., Falcón J.M., Forcada A., Guala I., Le Diréach L., Marcos C., Ojeda-Martínez C., Pipitone C., Schembri P.J., Stelzenmüller V., Stobart B., Santos R. 2010. Effects of no-take area size and age of marine protected areas on fisheries yields: a meta-analytical approach. Fish Fish. no. doi: 10.1111/j.1467-2979.2010.00401.x

Scient. ed.: V.D. Valavanis.

Received July 29, 2011. Accepted January9, 2012.

Published online May 7, 2012. 